\title{
A COMPARISON BETWEEN THE RECENT REGIONAL POLLEN RAIN AND THE SUB-RECENT VEGETATION IN FOUR MAJOR VEGETATION TYPES IN MINNESOTA (U.S.A.) ${ }^{1}$
}

\author{
C. R. JANSSEN \\ Botanical Museum and Herbarium, State University, Utrecht (The Netherlands)
}

(Received August 30, 1966)

SUMMARY

In four regions in Minnesota, covered by different types of vegetation, the regional pollen frequencies of a number of tree types and the composition of the regional forest type have been determined. It is concluded that:

(1) The forest types are recognizable from the pollen percentages.

(2) The ratio pollen percentage/vegetation percentage, the degree of representation of a pollen type, is different from one region to another.

(3) In regions with the same sort of topography the ratios vary within certain limits to such an extent that application of correction factors for a few pollen groups remains possible.

(4) The ratios are lowest when a tree species is frequent in the regional forest and highest when it is not very abundant.

\section{INTRODUCTION}

In the 50 years since the start of pollen analysis, surface sample studies in Europe and northern America have demonstrated that the pollen percentages calculated from a number of pollen types found in sediments do not reflect the actual composition of the vegetation. Many pollen types are either over-or under-represented in the pollen rain. If a pollen diagram is supposed to give an adequate picture of the changes in the vegetation then one should correct for differences of representation of the various pollen types. This has been done in Denmark by IVERSEN (1947) and FAEGRI and IVERSEN (1950, 1964), in Wisconsin by CuRTIS (1959), in Vermont by Davis (1963), in Greenland by IVERSEN (1952) and in Japan by TsukadA (1958). In all these studies the ratio of pollen percentage to the vegetational percentage, the $R$ values (DAVIS, 1963) were deter-

1 Contribution No. 43, Limnological Research Center, University of Minnesota, Minneapolis, Minn. (U.S.A.). 
mined by means of surface-sample studies in recent vegetation types. These ratios were then taken into account for a recalculation of the percentages of fossilpollen assemblages. $R$ values of most pollen types depart in varying degrees from 1 and consequently the percentage value of each pollen type may be corrected by its own $R$ value. This is the approach of Curtis and Davis. The method of Faegri and Iversen and Tsukada is less elaborated. They divide all the pollen types in a few groups, assigning each group a $R$ value on the basis of pollen production and/or surface samples.

These correction methods when applied to pollen diagrams more or less assume that the $R$ values do not vary considerably in time. DAvis (1963) has already pointed out that even when the recent $R$ value for a given type has been determined accurately it might depart from the recent one when transferred to the past by variations in climate (pollen production), sedimentation and the presence of different species. It is important to know to what extent the $R$ values might change if a completely different vegetation type is involved. Both Davis and Curtis in particular applied recent $R$ values to pollen assemblages from past vegetations that possibly were quite different from the recent vegetation. With these considerations in mind $R$ values were determined in four different forest types in Minnesota.

\section{REGIONAL VEGETATION TYPES}

Fig.1 shows the location of the four sites studied and the western boundaries of some coniferous elements. The Clearwater site is situated in predominantly xeric Quercus sp. woods and the Lake Sylvia site in mesic Acer saccharum-Tilia americana-Quercus rubra forest. In both areas conifers do not occur. In contrast, the Lake Itasca and Myrtle Lake sites are situated in a mixed coniferous-deciduous forest vegetation. The Myrtle Lake area differs from the other three areas in that it is not situated in morainic rolling upland but on the bottom of the formerly extensive glacial Lake Agassisz. Thus there is a much wider occurrence of lowland vegetation types than in the other three areas. The composition of the regional tree vegetation in the four areas is shown in Table $I$.

\section{DETERMINATION OF VEGETATION PERCENTAGE}

Following MCANDREws (1966) the forest composition has been calculated from data derived from the general land survey undertaken by the Federal Government in the past century. Importance Values (I.V.) were calculated from basal area, relative density and relative frequency (CuRTIS and McINTOSH, 1951). For comparison with the pollen percentages of the surface samples the I.V.'s 


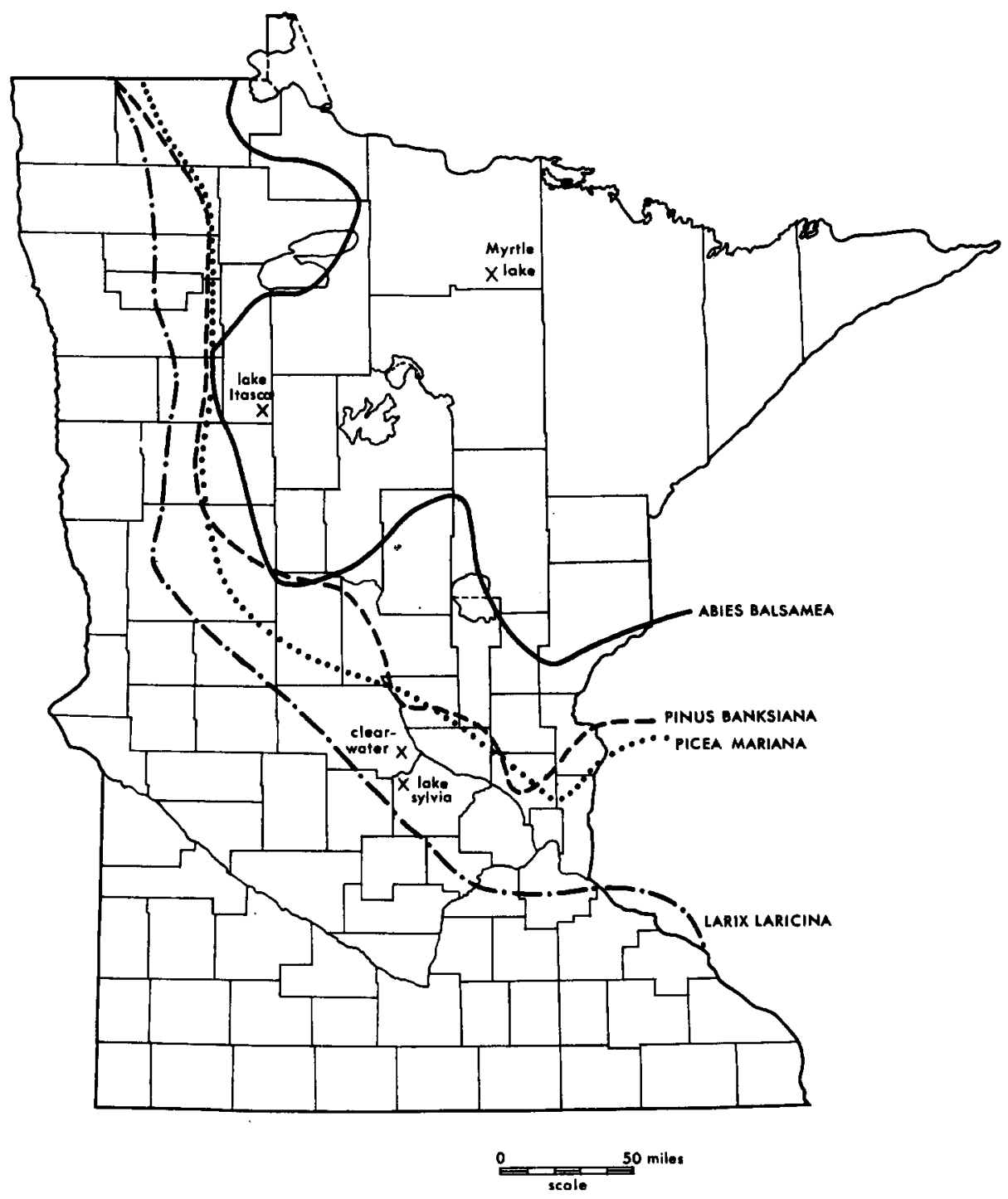

Fig.1. Location of the sites studied and distribution of some coniferous elements in Minnesota.

have been expressed as percentages of the sum of all $I . V$.'s $(\% I . V$.$) , Table I.$ The land has been surveyed around 1860 for the Clearwater and Lake Sylvia sites at the beginning of white settlement, around 1890 for the Lake Itasca site and around 1910 for the Myrtle Lake site, both just before settlement.

Certainly the vegetation underwent a change since the time of the landsurvey due to the logging and later suppression of fires. This change, however, does not usually affect the course of the curves of the tree-pollen types in the 
TABLE I

PERCENTAGE IMPORTANCE VALUES ${ }^{1}$

$\begin{array}{lcccc} & \text { Clearwater } & \text { Lake Sylvia } & \text { Lake Itasca } & \text { Myrtle Lake } \\ \text { Abies } & & - & 1.5 & 6.5 \\ \text { Picea } & - & - & 4.4 & 23.8 \\ \text { Pinus } & - & - & 59.4 & 6.7 \\ \text { Larix } & 11.1 & 2.3 & 7.5 & 33.3 \\ \text { Thuja } & - & - & 0.6 & 14.5 \\ \text { Populus } & 21.7 & 3.8 & 15.0 & 3.5 \\ \text { Betula } & 0.9 & 1.6 & 5.5 & 5.9 \\ \text { Quercus } & 53.4 & 17.1 & 3.1 & 1.1 \\ \text { Ulmus } & 8.7 & 24.7 & 0.7 & 0.7 \\ \text { Fraxinus } & 1.6 & 4.4 & 1.2 & 0.9 \\ \text { Tilia } & 1.2 & 9.1 & 0.3 & 1.1 \\ \text { Acer saccharum } & 0.4 & 18.7 & - & 0.2 \\ \text { Carya } & - & 0.4 & - & -\end{array}$

${ }^{1}$ Calculated from the Federal Land Survey for an area of 49 square miles (at Myrtle Lake 206 square miles).

upper part of Minnesota pollen diagrams. We, therefore, believe that the pollen content of the recent surface samples does not depart strongly from the subrecent pollen spectra.

One of the biggest problems in studies like this is how large the area is that contributes to the pollen rain. In forested regions most of the pollen seems to come from an area within a few miles of the sampling point (TsuKada, 1958). Similarly FAEGRI and IVERSEN (1964, p.104) are of the opinion that, judging from pollen-analytical experience, forests beyond the $10 \mathrm{~km}$ limit are of little importance to pollen diagrams. In our study, an area of 49 square miles around the Lake Sylvia, Lake Itasca and Clearwater sites was selected as a basis for the calculation of the vegetation percentages; twice as much as has been done previously in a study on the relation of the pollen rain of the forest immediately surrounding the sites (JANSSEN, 1966). This has been done to increase the statistical accuracy of the vegetation percentages. It was possible to do this because within the 7 miles boundary no break in the overall character of the regional vegetation occurs. At Myrtle Lake, as will be shown later the condition that most of the pollen grains are of "local" origin has not been met. For that reason at this site the area used for the calculation of the vegetation percentages has been enlarged tentatively to 206 square miles (six townships).

DETERMINATION OF THE POLLEN PERCENTAGES

Pollen percentages have been expressed as averages from a number of surface samples taken along transects in order to study the effect of distance 
from the pollen source (JANSSEN, 1966). Only samples that show regional values for the pollen types included in the pollen sum have been used. In Table II-V the variation in pollen percentages of the individual samples, the Average Regional Pollen percentage (A.R.P.) and the samples used in the calculation of the averages have been shown ${ }^{1}$. The pollen sum comprises only the tree types mentioned in the land survey. Therefore, for the Clearwater and Lake Sylvia sites the coniferous pollen types (excl. Larix) have been excluded from the pollen sum. Pollen grains from these types arrive in the sediment by long distance transport from the conifer belt in the east and thus constitute the "extra regional" pollen rain. Their quantity depends on the distance to this other major vegetation type, not on their presence in the regional forest. The knowledge that a particular species is absent in the region is an advantage which all recent surface studies have in common. In fossil assemblages it is often impossible to tell whether a small percentage comes from a few trees in the region or from stands at a distance. Therefore A.R.P.'s based upon a pollen sum including conifers have also been mentioned.

Because the different species of Fraxinus were not always recognized in the land survey, one combined percentage for that tree has been calculated.

Trees below 5-inch diameter and shrubs are as a rule not recorded in the land survey and thus are excluded from the pollen sum (e.g., Corylus). However, Betula and Ostrya are included. The lowland shrub Betula pumila occurs in the Lake Itasca and Myrtle areas and might add to the pollen rain of the upland tree Betula papyrifera. Likewise, small trees of Ostrya virginiana might not have been recorded while still contributing to the pollen rain.

\section{RESULTS AND DISCUSSION}

The results have been displayed in one figure and one table. In Fig. 2 the \% I.V. and the A.R.P. have been shown for the four sites. On top of each site go the types that do not have any record in the Federal Survey and thus would have an infinite $R$ value. These are the elements that either are absent in the area used for the calculation of the \% I.V. or escaped the attention of the surveyors because they were too small in size. The other pollen types have been arranged according to decreasing $R$ values. For the Clearwater and Lake Sylvia sites the A.R.P. based upon a pollen sum including conifers has been indicated by arrows.

In Table VI the $R$ values have been shown; in addition at Clearwater and Lake Sylvia those values, between brackets, based upon a calculation with a A.R.P. excl. conifers. They do not change the overall picture.

From Fig. 2 it appears that the character of the regional forest is clearly recognizable from the regional pollen rain. The regional pollen rain from the

\footnotetext{
${ }^{1}$ Attention is drawn to the fact that the A.R.P. differs from that in the transect studies be-
} cause of the selection of a different pollen sum. 
TABLE II

REGIONAL POLLEN PERCENTAGES AT CLEARWATER

\begin{tabular}{|c|c|c|c|c|c|c|c|c|c|c|}
\hline & \multicolumn{2}{|c|}{ Sample no. } & \multirow[b]{2}{*}{6} & \multirow[b]{2}{*}{$I I$} & \multirow[b]{2}{*}{12} & \multirow[b]{2}{*}{13} & \multirow[b]{2}{*}{14} & \multirow[b]{2}{*}{15} & \multirow[b]{2}{*}{16} & \multirow[t]{2}{*}{ A.R.P } \\
\hline & 4 & 5 & & & & & & & & \\
\hline Pinus & 8.5 & 11.5 & 10.8 & 10.3 & 7.1 & 6.9 & 9.9 & 8.6 & 9.1 & 9.45 \\
\hline Abies & - & - & - & - & - & - & - & - & $\ldots$ & - \\
\hline Picea & - & - & - & - & 0.4 & - & $\ldots$ & - & 0.4 & 0.08 \\
\hline Larix & - & -- & - & - & 0.4 & 0.3 & 0.35 & 0.4 & - & 0.07 \\
\hline Betula & 10.0 & 10.5 & 11.0 & 4.3 & 4.2 & 7.1 & 5.5 & 3.9 & 3.5 & 6.9 \\
\hline Populus & 0.7 & - & 1.0 & - & - & 0.6 & 0.35 & 2.7 & 3.0 & 0.93 \\
\hline Ulmus & 5.3 & 4.5 & 4.7 & 2.3 & 3.3 & 4.6 & 4.7 & 3.9 & 6.0 & 4.5 \\
\hline Fraxinus & 2.5 & 1.5 & 2.3 & 1.1 & 2.9 & 1.6 & 1.1 & 1.2 & - & 1.4 \\
\hline Quercus & 74.8 & 79.6 & 74.0 & 79.0 & 84.5 & 83.0 & 82.5 & 83.9 & 83.5 & 80.5 \\
\hline Tilia & 1.1 & 2.5 & 1.3 & 0.55 & 0.4 & 0.3 & 0.7 & 1.2 & 0.3 & 0.9 \\
\hline Acer saccharum & - & - & 0.65 & - & - & - & 0.35 & 0.4 & - & 0.17 \\
\hline Ostrya & 0.35 & - & 1.7 & 1.4 & 1.3 & 1.2 & 2.2 & 0.8 & 0.8 & 1.2 \\
\hline Carya & 0.35 & - & 1.0 & - & 0.4 & 0.3 & - & 0.8 & - & 0.34 \\
\hline Celtis & - & - & 0.35 & - & 一 & 0.3 & 0.7 & - & - & 0.17 \\
\hline Pollen sum & 281 & 199 & 297 & 349 & 240 & 321 & 274 & 255 & 231 & 2362 \\
\hline
\end{tabular}

TABLE III

REGIONAL POLLEN PERCENTAGES AT LAKE SYLVIA

\begin{tabular}{|c|c|c|c|c|c|c|c|c|c|c|}
\hline & Samp & e no. & & & & & & & & A.R.P. \\
\hline & 3 & 4 & 6 & 7 & 8 & 9 & 10 & 11 & 12 & \\
\hline Pinus & 42.5 & 11.5 & 10.1 & 26.5 & 8.4 & 12.7 & 7.9 & 27.3 & 18.8 & 16.8 \\
\hline Abies & 0.5 & - & 0.5 & - & - & 0.6 & - & 0.5 & 0.8 & 0.3 \\
\hline Picea & 0.5 & - & - & - & - & 0.3 & - & 0.9 & - & 0.18 \\
\hline Larix & 0.5 & - & - & - & 0.4 & - & - & 一 & -- & 0.1 \\
\hline Betula & 4.3 & 8.6 & 4.5 & 8.2 & 7.0 & 7.4 & 3.4 & 6.9 & 5.5 & 6.1 \\
\hline Populus & 0.5 & 1.4 & 3.4 & 2.0 & 0.4 & 0.9 & 1.4 & 1.8 & - & 1.2 \\
\hline Ulmus & 40.4 & 47.6 & 41.0 & 38.9 & 47.3 & 39.5 & 40.7 & 30.1 & 37.9 & 44.0 \\
\hline Fraxinus & 6.2 & 1.1 & 2.2 & 2.7 & 1.5 & 1.2 & 2.0 & 5.1 & 6.6 & 2.9 \\
\hline Quercus & 26.0 & 26.0 & 37.6 & 36.1 & 27.5 & 45.5 & 37.3 & 33.7 & 35.3 & 34.2 \\
\hline Tilia & 3.8 & 1.4 & 3.9 & 4.1 & 5.1 & 1.5 & 3.1 & 6.0 & 0.4 & 3.2 \\
\hline Acer saccharum & 3.7 & 4.3 & 1.7 & 3.4 & 4.7 & 3.3 & 2.2 & 7.4 & 3.9 & 3.8 \\
\hline Ostrya & 2.8 & 5.7 & 3.4 & 2.0 & 2.2 & 2.1 & 5.4 & 1.8 & 3.9 & 3.4 \\
\hline Carya & 0.5 & 1.8 & 0.5 & 0.6 & 0.4 & 0.3 & 1.1 & 2.7 & 1.2 & 1.0 \\
\hline Celtis & 0.5 & 0.35 & - & - & - & - & 0.8 & 0.5 & 0.8 & 0.35 \\
\hline Pollen sum & 211 & 277 & 178 & 147 & 273 & 347 & 353 & 216 & 255 & 2267 \\
\hline
\end{tabular}


TABLE IV

REGIONAL POLLEN PERCENTAGES AT LAKE ITASCA

\begin{tabular}{|c|c|c|c|c|c|c|c|c|c|c|c|c|}
\hline & \multicolumn{11}{|c|}{ Sample no. } & \multirow[t]{2}{*}{ A.R.P. } \\
\hline & 15 & 16 & 17 & 18 & 19 & 20 & 21 & 22 & 30 & 31 & 32 & \\
\hline Pinus & 72.4 & 67.9 & 69.5 & 82.5 & 69.0 & 53.6 & 70.5 & 77.9 & 76.2 & 74.7 & 79.0 & 74.5 \\
\hline Abies & 2.8 & 1.3 & 2.9 & 0.9 & 1.2 & 1.1 & 2.9 & 2.7 & 0.8 & 1.5 & 2.0 & 1.9 \\
\hline Picea & 1.4 & 1.3 & 1.2 & 2.4 & 0.6 & 0. & 1.5 & 1.4 & 2.1 & 0.4 & 1.6 & 1.3 \\
\hline Larix & - & - & - & - & - & 0.3 & 0.3 & 0.2 & - & - & - & 0.07 \\
\hline Betula & 7.1 & 14.1 & 11.8 & 7.2 & 19.6 & 13.9 & 13.0 & 10.2 & 6.3 & 11.6 & 6.6 & 11.5 \\
\hline Populus & 0.5 & - & - & 0.3 & 0.6 & 0.3 & 0.5 & 0.4 & 2.1 & 1.1 & 0.3 & 0.56 \\
\hline Ulmus & 0. & 0.9 & 2.6 & 1.2 & 1.5 & 2.5 & 0.8 & 0.4 & 0.4 & 0.9 & 2.0 & 1.3 \\
\hline Fraxinus & 3.8 & 4.5 & 1.2 & 0.7 & 1.8 & 0.6 & 1.0 & 0.8 & 3.4 & 0.9 & 1.0 & 1.8 \\
\hline Quercus & 10.0 & 7.0 & 7.9 & 3.4 & 8.0 & 5.3 & 6.6 & 4.3 & 7.1 & 5.7 & 5.3 & 6.5 \\
\hline Tilia & 0.7 & 0.6 & - & - & - & 0.3 & 0.5 & 0.2 & - & 0.4 & - & 0.24 \\
\hline Acer sacch. & - & - & 0.6 & - & - & 一 & 0.5 & - & - & 0.2 & - & 一 \\
\hline Ostrya & - & 0.2 & - & 0.5 & 0.3 & 0.5 & 1.3 & 1.4 & - & 0.9 & 0.3 & 0.3 \\
\hline Carya & 一 & - & 0.6 & - & 0.6 & - & - & 0.2 & - & - & 0.3 & 0.15 \\
\hline Celtis & - & - & - & - & - & 0.3 & - & - & - & - & - & 0.02 \\
\hline Pollen sum & 421 & 460 & 341 & 413 & 346 & 290 & 378 & 440 & 237 & 527 & 303 & 4087 \\
\hline
\end{tabular}

TABLE V

REGIONAL POLLEN PERCENTAGES AT MYRTLE LAKE

\begin{tabular}{lcrrrrr}
\hline & \multicolumn{2}{c}{ Sample no. } & & & & A.R.P. \\
\cline { 2 - 6 } & \multicolumn{1}{c}{11} & 22 & \multicolumn{1}{c}{31} & \multicolumn{1}{c}{45} & \multicolumn{1}{c}{57} & \\
\hline Pinus & 55.7 & 61.2 & 69.2 & 57.0 & 63.0 & 62.6 \\
Abies & 2.5 & 3.1 & 0.6 & 1.5 & 2.8 & 1.8 \\
Picea & 8.5 & 6.1 & 8.2 & 5.7 & 5.1 & 6.8 \\
Larix & - & 0.2 & 0.2 & - & - & 0.09 \\
Betula & 15.0 & 12.8 & 4.9 & 15.3 & 13.9 & 11.0 \\
Populus & 0.5 & - & - & - & - & 0.09 \\
Ulmus & 4.9 & 2.4 & 1.9 & 2.2 & 2.8 & 2.8 \\
Fraxinus & 5.7 & 6.2 & 7.8 & 10.3 & 7.1 & 7.4 \\
Quercus & 5.1 & 5.7 & 6.5 & 7.1 & 7.3 & 6.3 \\
Tilia & - & 0.6 & 0.2 & 0.5 & 0.3 & 0.34 \\
Acer saccharum & - & 0.2 & - & 0.3 & - & 0.09 \\
Ostrya & 0.5 & 0.6 & - & - & 0.5 & 0.34 \\
Carya & - & - & 0.2 & - & - & 0.05 \\
Celtis & - & - & 0.2 & 0.3 & - & 0.05 \\
Pollen sum & 364 & 454 & 525 & 369 & 354 & 2066 \\
\hline
\end{tabular}


deciduous forest, for instance, shows higher percentages for Acer, Tilia, Ulmus and Carya and lower values of Quercus than in the regional pollen rain of the mixed deciduous-coniferous forest types in showing a low A.R.P. of Pinus. Picea is only strongly represented in the regional pollen rain at Myrtle Lake where it shows higher I.V.'s in the vegetation.

As expected, however, the pollen percentages differ distinctly from the vegetation percentages and more important the $R$ values of pollen types in one region usually are different from those in other regions.

\section{The Clearwater, Lake Sylvia and Lake Itasca sites}

Although the $R$ values vary, these sites have in common an over-representation of Betula, while Quercus, Ulmus and Fraxinus are more or less equally represented; Tilia and Picea are moderately under-represented and Acer, Populus and Larix are strongly under-represented in the pollen rain. This is roughly the same pattern as is found in most European studies. With the exception of Quercus this is also basically the same pattern found by DAVIS and GoodLeTT (1960) in Vermont and by Potzger et al. (1956) in Quebec. In my study, the $R$ values do not differ by more than a factor of 3 (Betula and Ulmus), often less. Ostrya, however, shows a much higher $R$ value at Clearwater than at Lake Sylvia. This might be explained by assuming that at Clearwater most trees of Ostrya were of too small a size to be recorded by the surveyors.

The relatively unimportant differences in $R$ values seem to favour the establishment of groups for which rough correction factors for different types

TABLE VI

$R$ VALUES FOR THE SITES STUDIED ${ }^{1}$

\begin{tabular}{|c|c|c|c|c|c|c|}
\hline \multirow[b]{2}{*}{ Betula } & \multicolumn{2}{|c|}{ Clearwater } & \multicolumn{2}{|c|}{ Lake Sylvia } & \multirow{2}{*}{$\begin{array}{l}\text { Lake Itasca } \\
2.1\end{array}$} & \multirow{2}{*}{$\begin{array}{l}\text { Myrtle Lake } \\
1.9\end{array}$} \\
\hline & 7.6 & $(7.0)$ & 3.8 & (3.2) & & \\
\hline Quercus & 1.5 & $(1.42)$ & 2.0 & $(1.7)$ & 2.1 & 5.7 \\
\hline Fraxinus & 0.85 & $(0.81)$ & 0.65 & $(0.57)$ & 1.5 & 8.2 \\
\hline Ulmus & 0.51 & $(0.47)$ & 1.8 & $(1.5)$ & 1.7 & 4.0 \\
\hline Tilia & 0.75 & $(0.67)$ & 0.35 & $(0.30)$ & 0.73 & 0.31 \\
\hline Acer saccharum & 0.42 & $(0.38)$ & 0.20 & $(0.17)$ & $\ldots$ & 0.04 \\
\hline Ostrya & 4.0 & $(3.7)$ & 0.22 & $(0.18)$ & - & $\ldots$ \\
\hline Populus & 0.04 & $(0.04)$ & 0.3 & $(0.26)$ & 0.04 & 0.025 \\
\hline Larix & 0.015 & $(0.013)$ & 0.04 & $(0.035)$ & 0.01 & 0.003 \\
\hline Pinus & - & &..- & & 1.26 & 9.3 \\
\hline Abies & $\ldots+\ldots$ & & $\ldots$ & & 1.27 & 0.28 \\
\hline Picea & $\ldots$ & & $\ldots$ & & 0.30 & 0.29 \\
\hline
\end{tabular}

${ }^{1}$ Between brackets $R$ values based upon a pollen sum without conifers (Clearwater and Lake Sylvia). 


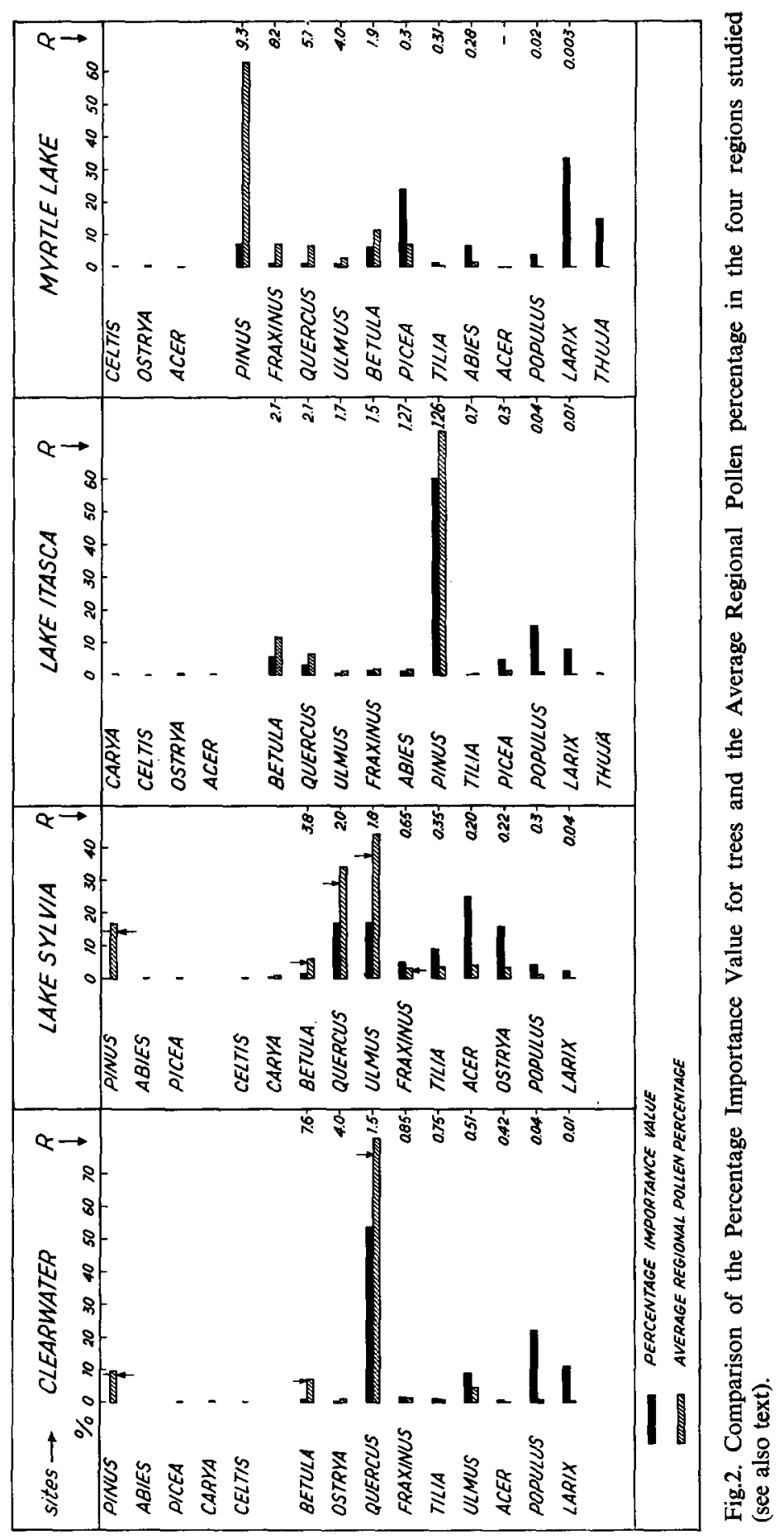

Rev. Palaeobotan. Palynol., 2 (1967) 331-342 
of vegetation may be validly applied. In such a system the pollen percentages of Betula should be reduced and the percentages of the strongly under-represented pollen types should be increased.

I do not, however, propose at present to introduce correction factors that can applied to the Postglacial of Minnesota until more data from other vegetation types that may have been present during the Postglacial are available.

In spite of the relative unimportance of the variation in $R$ values they do indeed vary and to such an extent that application of the exact $R$ value of each pollen type obtained from one vegetation to another would introduce an exactness that in fact does not exist.

The pattern that emerges from Fig. 2 is that as a rule the highest $R$ value is found for the type that plays a very unimportant part in the vegetation. In its extreme this is of course true for those types that do not occur in the regional vegetation. The $R$ value would then be unlimited. Further a low vegetation percentage is usually accompanied by higher $R$ values. In contrast $R$ values are depressed in cases where the type is important in the vegetation.

This seems to be true for many other representation studies, although the parameters used for the calculation of the vegetation percentages are different than those used here.

The $R$ values reported by TsukadA (1958) in the various vegetation belts in Japanese mountains follow this trend. DAvIS (1963) reported high $R$ values for Quercus, Pinus and Alnus in Vermont and less than $0.2 \%$ basal area in the forest. The $R$ value of Quercus in particular is unusually high in Vermont. In my study it is more in line with the values found in most European studies (e.g., SteinberG, 1944; Mullenders, 1962; Heim, 1962; Müller, 1937). In Europe, Pinus and Betula are among the types that show the highest $R$ values, usually where Pinus and Betula are not abundant in the vegetation (cf. HeIM, 1962; MüLLER, 1937). TsukAdA (1958) found a lower $R$ value for Betula in Japan in a forest belt where it is abundant in the vegetation. Pinus at Lake Itasca is not so over-represented as is commonly accepted (see also MCANDrews, 1966). Part of the explanation for this phenomenon is arithmetical. An increase in vegetation percentage which would result in a proportional increase of the absolute number of produced pollen grains results in a diminished increase of the pollen percentages, especially in the higher percentage bracket (FAGERLIND, 1952). As a result of this the $R$ value for species that show a substantial vegetation percentage should be lower. Secondly, especially for the types that are present in low frequencies in the region the contribution of extra-regional pollen is relatively more significant than for elements that are very frequent in the regional forest. Thirdly, the statistical error for species that occur in low frequencies in the forest might result in either a too high or too low vegetation percentage. 
The $R$ values calculated for the Myrtle Lake site are markedly different from those of the former three sites. Ulmus and Fraxinus that where approximately equally represented are here distinctly over-represented. Also Quercus shows a much higher $R$ value as does Pinus, when compared with the Lake Itasca site. Betula that showed for the other three sites the highest $R$ value is much reduced. This demonstrates that the same relationship between the level of the vegetation percentages and the $R$ values exist as reported for the other three sites. The most important reason for the trend to over-representation at Myrtle Lake may be that the extra-regional pollen rain is very important. More than $90 \%$ of the tree pollen comes from outside the area occupied by bog species, thus from areas at a relatively large distance. For this reason the area selected for the calculation of the vegetation percentages has been enlarged considerably, but it is quite possible that the area that contributes to the pollen rain is still larger. If a larger area has been selected the overall vegetation would have been more homogeneous and more upland areas would have been included resulting in higher vegetation percentages of upland species and thus lower $R$ values. The relatively unimportant contribution of the tree bog species to the pollen rain may thus be the main reason of the large area that contributes to the pollen rain at the sampling site resulting in high $R$ values.

Of all the regions in Minnesota the vegetation on the former beds of glacial Lake Agassisz is the vegetation that comes closest to the possible vegetation of the Picea-Larix zone during the Late Glacial of the lake States. In contrast to the Myrtle Lake region the Picea-Larix zone shows very low values of Pinus, demonstrating that Pinus must have been absent or very rare.

Samples of Late Glacial age from the Upper Midwest frequently show substantial percentages of deciduous trees. It has been a point of discussion whether these elements have been part of the vegetation, have been transported by long distance or were redeposited from interglacial deposits (cf. WRIGHT, 1964). If we assume that in the Late Glacial the delivery capacity (sensu FAGERLIND, 1952) of Picea and Larix was small as is now the case in the Myrtle Lake area, high $R$ values may be expected for the deciduous upland trees. In the absence of Pinus the $R$ values may be pushed up very high indeed, resulting in relatively high pollen percentages even when these elements are only a minor part of the vegetation.

\section{REFERENCES}

CuRTIs, J. T., 1959. The Vegetation of Wisconsin. Univ. Wisconsin Press, Madison, Wisc., $657 \mathrm{pp.}$ CURTIS, J. T. and McINTosh, R. P., 1951. An upland forest continuum in the prairie-forest border region of Wisconsin. Ecology, 32: 76-496.

Davis, M. B., 1963. On the theory of pollen analysis. Am. J. Sci., 261: 897-912. 
Davis, M. B. and GoodletT, J. C., 1960. Comparison of the present vegetation with pollen spectra in surface samples from Brownington pond, Vermont. Ecology, 41: 346-357.

Faegri, K. and Iversen, J., 1950. Textbook of Modern Pollen Analysis. Munksgaard, Copenhagen, $168 \mathrm{pp}$.

FAEGri, K. and IverSEN, J., 1964. Textbook of Pollen Analysis. Munksgaard, Copenhagen, 2. ed., $237 \mathrm{pp}$.

FAGERLIND, F., 1952. The real signification of pollen diagrams. Botan. Notiser, 1952: 185-224.

HEIM, J., 1962. Recherches sur les relations entre la végétation actuelle et le spectre pollinique récent dans les Ardennes Belges. Bull. Soc. Roy. Botan. Belg., 96: 5-92.

IVERSEN, J., 1947. Discussionsindlaeg i Nordiskt kvartärgeologiskt möte den 5-9 november 1945. Geol. Fören. Stockholm Förh., 69: 241-242.

IVERSEN, J., 1952. Origin of the flora of western Greenland in the light of pollen analysis. Oikos, 4: $85-103$.

JANSSEN, C. R., 1966. Recent pollen spectra from the deciduous and coniferous-deciduous forests of northern Minnesota: a study in pollen dispersal. Ecology, 47(5): 804-825.

MCANDrews, J. H., 1963. Late and post-Glacial Vegetation History of the Prarie-Forest Transition in Northwestern Minnesota. Thesis, Univ. Minnesota, Minneapolis, Minn., 99 pp.

MCANDREWs, J. H., 1966. Postglacial history of prairie, savanna, and forest in northwestern Minnesota. Torrey Botan. Club Mem., 22(2): 72 pp.

Mullenders, W., 1962. Les relations entre la végétation et les spectres polliniques en foret du Mont Dieu (département des Ardennes, France). Bull. Soc. Roy. Botan. Belg., 94: 131-138.

Müller, P., 1937. Das Hochmoor von Etzelwil. Ber. Geobotan. Forschungsinst. Rübel, Zürich, 1936: 85-106.

Potzger, J. E., Courtemanche, A., Sylvio, B. M. and Hueber, F. M., 1957. Pollen from moss polsters on the mat of Lac Shaw bog Quebec, correlated with a forest survey. Butler Univ. Studies, 13: 24-35.

SteinberG, K., 1944. Zur spät- und nacheiszeitlichen Vegetationsgeschichte des Untereichsfeldes. Hercynia, 3: 529-587.

Tsukada, M., 1958. Untersuchungen über das Verhältnis zwischen dem Pollengehalt der Oberflächenproben und der Vegetation des Hochlandes Shiga. Osaka City Univ., Inst. Polytechn., J., Ser. D., 9: 217-234.

Wright, H. E., 1964. Aspects of the Early Postglacial forest succession in the Great Lakes region. Ecology, 45: 439-448. 